\title{
A Study on Tectonic and Sedimentology in Order to Fault Rupture Potential in Coasts the Makran Sea
}

\author{
Mohyeddin Ahrari-Roudi \\ Oceanography Department, Marine Sciences Faculty, Chabahar Maritime University, Chabahar, Iran \\ Email: ahrari.geologist@gmail.com
}

How to cite this paper: Ahrari-Roudi, M. (2017) A Study on Tectonic and Sedimentology in Order to Fault Rupture Potential in Coasts the Makran Sea. Open Journal of Geology, 7, 1269-1286.

https://doi.org/10.4236/ojg.2017.79084

Received: July 29, 2017

Accepted: August 29, 2017

Published: September 1, 2017

Copyright $\odot 2017$ by author and Scientific Research Publishing Inc. This work is licensed under the Creative Commons Attribution International License (CC BY 4.0).

http://creativecommons.org/licenses/by/4.0/

\begin{abstract}
Makran zone is one of the largest accretionary wedges in the world. This research had used methods such as studies of Office and library, field observation and surveying that several field visits, sampling, registered structural evidence, Laboratory studies, Data analysis, interpretation and conclusions. The most important objective of this study is assessment of Tectonics and hazard Potential in Coasts the Oman Sea based on tectonics and sedimentology. The northward movement and subduction of Oman oceanic lithosphere beneath Iranian micro-plate at a very shallow angle and at high rate is responsible for active orogenesis and uplift. Detailed seismological and geological information in planning is extremely essential to avoid any disaster. It is to be remembered that seismicity does not remain fixed in an area but migrates slowly with time. Thus, the planners are expected to be more concerned with the building code and prevention strategies. It is also important to mention that the Coastal zones are always vulnerable to natural hazards and liquefaction. The geomorphology of an area is the first indicator of on-going tectonic activity. In order to measure the amount of deformation due to tectonic processes, the initial geometry of the geomorphic markers is reconstructed accurately. Study of sediments shows that abundant shell fragments organized in laminae also favor a storm origin. Storm deposits contain no internal mud layers and rarely contain pieces of mud. Maximum deposit thickness is near the shore, and landward thinning of the deposit is commonly abrupt. Storm deposits fill in topographic lows, and the upper surface is relatively uniform in elevation alongshore. Finally, landforms of tectonically active regions and sediments are controlling factors interactions between tectonic, sedimentary, climatic, and surficial processes.
\end{abstract}

\section{Keywords}

Tectonics, Sediments, Makran, Fault Rupture Potential, Accretionary Wedges 


\section{Introduction}

The Makran Trench is the physiographic expression of a subduction zone along the northeastern margin of the Gulf of Oman adjacent to the southwestern coast of Balochestan of Pakistan and the southeastern coast of Iran. In this region the oceanic crust of the Arabian Plate is being subducted beneath the continental crust of the Eurasian Plate. Makran is one of the largest accretionary wedges on the globe, formed by the convergence between the Eurasian and the Arabian Plates. The Makran subduction zone has not been studied extensively, but the $1945 \mathrm{Mw} 8.1$ earthquake and subsequent tsunami, as well as more recent mid magnitude, intermediate depth $(50-100 \mathrm{~km})$ seismicity, demonstrate the active seismic nature of the region [1]. Recent increases in regional GPS and seismic monitoring now permit the modeling of strain accumulations and seismic potential of the Makran subduction zone. Subduction zone seismicity indicates that the eastern half of the Makran is presently more active than the western half.

In a plate tectonic setting like that of the Makran Accretionary Complex of Oman Sea, a fairly high earthquake activity would be expected, as in many of the other major Accretionary complexes (subduction zones) around the world. But this region which is located between the Zendan-Minab Fault System and Oranch-Nal Fault Zone shows relatively low seismicity in comparison with the surrounding region. Better documented tsunami events in the Makran subduction zones are three, including two events of seismic origin, and one of unknown origin. The latest event is the major earthquake-generated tsunami of 1945 in eastern Makran that ruptured approximately one-fifth the length of the subduction zone [1]. It is important to note that, the epicenter of this event is also close to the Sonne Fault which has created segments on the Makran Subduction Zone.

The crossing points between Makran Subduction Zone and these oblique fault zones can be a location for occurrence of major earthquake activities. However, more studies are required for further clarification. In contrast to the east, the plate boundary in western Makran has no clear record of historical as well as instrumental great events. The large changes in seismicity between eastern and western Makran suggest segmentation of the subduction zone. In the Makran region, the Arabian Plate subducts beneath the Eurasian Plate at $\sim 4 \mathrm{~cm} / \mathrm{yr}$. This subduction is associated with an accretionary wedge of sediments which has developed since the Cenozoic [2] [3]. To the west, the Makran Trench is connected by the Minab Fault system to the Zagros fold and thrust belt [4]. To the east, the Makran Trench is bounded by the transpressional strike-slip Oranch-Nal and Chaman Faults, which connect to the Himalayan orogeny.

Tsunami deposits are difficult to identify in arid siliciclastic sand at coastal settings due to numerous erosive post-depositional processes acting on the sediment. The action of daily tides, wind driven waves, storm waves, and even localized processes such as bioturbation can potentially erase traces of these events from the sediment record in short periods i.e. 10 years or less [5] [6].

The most important objective of this study is assessment of Tectonics and ha- 
zard Potential in Coasts the Oman Sea based on tectonic and sedimentology. Sea level is the common and unifying element of coastal tectonics. Present sea level, the universal datum for measuring elevation, is the most convenient reference for detecting ongoing vertical crustal movement and assessing short-term tectonic stability in coastal areas [7]. Long-term tectonic stability along most passive-margin coastlines is expressed stratigraphically by undeformed continental and marine sediments that underlie flat coastal plains and continental shelves and geomorphically by broad accretionary strandline terraces that consist of subdued beach ridges separated by abandoned tidal flats.

\section{Geological and Tectonic Setting}

The study area between latitudes 25 degrees to 25 degrees and 45 minutes north and longitude 56 degrees 45 minutes' lengths up to 61 degrees and 52 minutes north of the Sea of Oman and the north-eastern Sistan and Baluchestan province is located. From the perspective of geology of this area is located in this region, this region is structurally the two outer parts (coastal) and an internal split. The study area is located in the external part, the structure of the Makran coast all and area larger than the selected range (Figure 1).

Basic features of this section of Ophiolite, flyschfacies sedimentary deposits and non-exposed older rocks of the Cretaceous. Ophiolite complexes of the region,

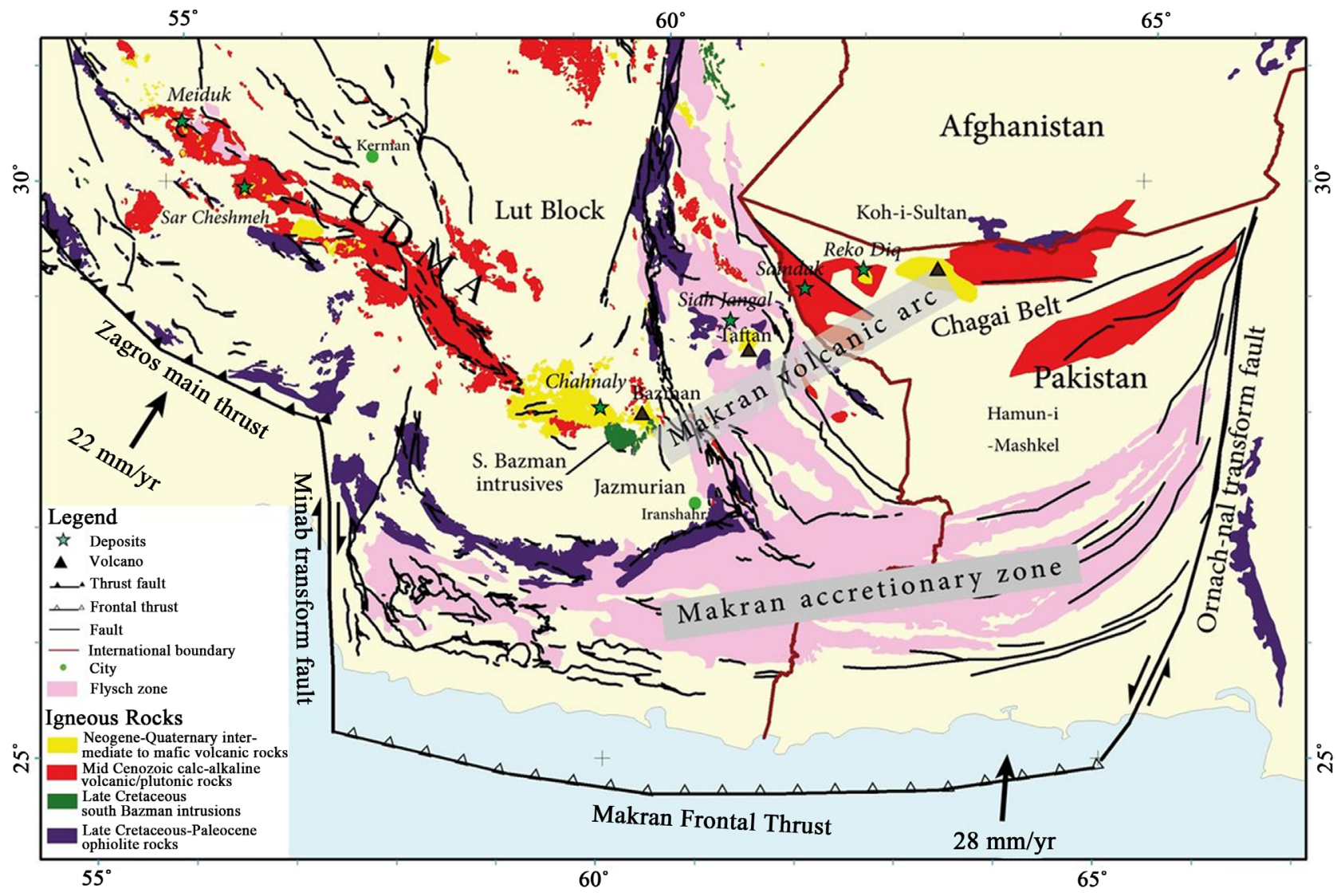

Figure 1. Simplified geological map of the study area with main thrusts separating the four principal litho-tectonic units. 
more and more or less continuous strips are often outcrops along the main longitudinal fault. The fact that normal faulting occurs along the coast only suggests a trench-parallel structural discontinuity, which is not well understood [8]. On the other hand, the study area, including areas where due to specific conditions of climate and geology of these a level fluctuations during the various geological processes of weathering and erosion and tectonic activity caused by the subduction of Omanandup Makranbulge screen, unique structures and mainly clastic sedimentary rocks formed. Differentrock units in the coastal zone and land overlooking the sea are marl of Miocene age, marlands and stone units $\mathrm{Mi}$ ocene-Pliocene sediments of sand and silt deposits of alluvial fans and animal shells. Above these sequences, there is an abrupt passage up without any apparent unconformity, through reefal Burdigalian limestones, and locally a harzburgite conglomerate development, into neritic sequences with minor turbidites, extending into the Pliocene units. Generally, sequence stratigraphy, the study area four Mio-Pliocene rocks, rocks Miocene, Pliocene and Quaternary rock units have been formed rock units that Neogene and Quaternary units are known as [9]. Quaternary deposits in the Makran coastal sediments of the Pliocenes tratigraphic column on the Pliocene conglomerate fall, but in the study area includes the coastal areas.

The Makran accretionary complex is characterized by a number of features associated with escaping water and methane. Mud volcanoes are found onshore in both Iran and Pakistan, and cold seeps exist offshore for example Tang Mud volcano. The formation of an island (Zalzala Jazeera) after the 2013 Balochestan earthquakes is thought to be the result of a mud volcano. Many studies have documented the complex relationships between rock uplift and climatically-modulated erosion efficiency and discussed the respective influence of these driving factors on channel incision [10] [11] [12].

\section{Material and Methods}

In this research had been used the following methods:

Office and library studies: At this stage, books, theses, articles, reports and geological maps related to the subject studied. Working as quantitative-qualitative methods (heuristic) and research-oriented and library studies such as research and scientific resources related to the topic of the previous studies and then collected and examined. Field Studies: At this stage contain field observation and surveying that several field visits, sample collection, registered structural evidence (photographed and documented in structural geology features) is done. That means three locations include Gowader, Chabahar, Konarak and Pozm were studied along the outcrop belt (Makran zone) in southeastern Iran. This study is based on 85 hand samples and 62 sediments samples that were collected from the study areas. Laboratory studies: In the other hand First, using aerial photographs and satellite images, using Google Earth and GIS, geological maps, topography, tectonic and seismic data was conducted. Data analysis, interpretation and con- 
clusions: The initial processing by computer skills such as Excel and final processing using software was computed.

The geomorphology of an area is the first indicator of on-going tectonic activity. In order to measure the amount of deformation due to tectonic processes, the initial geometry of the geomorphic markers reconstructed accurately. Landforms of tectonically active regions reflect interactions between tectonic, climatic, and surficial processes [10] [13] [14]. Accepting steady state implies that the landscape morphology is adjusted so that river incision and hill slope erosion rates balance rock uplift rates (e.g. [15]). We applied the tools commonly used in tectonic geomorphology studies; following the principle that drainage network may be related to recent surface, mostly tectonic movements.

Sediments were collected in coasts of Makran were selected based on the presence of the allochthonous bivalve tsunami bed (TB) found close to the surface or exposed in tidal creek sections. The shell unit could be traced along the tidal creeks $(\mathrm{b} 80 \mathrm{~cm})$ and in addition many test pits were dug checking the continuity of the unit. Of these test pits (60 - $650 \mathrm{~cm}$ deep), eight were selected to collect large samples of bivalves and eight short percussion cores were collected to document the detailed stratigraphy and continuity of the shell bed. Surface-elevation data were collected within the lagoon using a differential GPS (D-GPS) and interpolated to create a digital elevation model (DEM) of the surface topography.

The sedimentary characteristics of shell beds within an interpreted tsunami deposit from Lipar Lagoon, Oman were examined using shell taphonomy and high-resolution particle-size analysis.

Multivariate analysis of the particle-size data was conducted using Ward's algorithm (which emphasizes minimal within-group variance [16]; to produce a Qmode cluster dendrogram in the statistical program SPSS $_{23}$. This clustering technique creates hierarchical groupings based upon similarity determined from equally weighted Euclidean distance measurements of the entire grain size $(0.0375-2000 \mu \mathrm{m})$ distribution for each sample analyzed [17] [18]. A full discussion of cluster analysis and its application to SPSS $_{23}$ is provided. Study the following subjects the present research was completed:

Geology is the key to a meaningful inventory of past seismic activity, and from that, a long-term seismic hazards assessment. The data come from geomorphology, structural geology, sedimentology and from various geophysical records. Both primary (faults, fractures) and secondary (liquefaction, slides, tsunamis, etc.) evidence have to be considered. Ideally, a pale seismic event is recorded by multiple types of field evidence. Dating plays a central role in the establishment of a reliable chronology allowing meaningful seismic hazard assessment.

\section{Discussion and Interpretation}

The region lies near the Arabian, Indian and Eurasian Plate boundaries (Figure 2). Tectonic collision process is taking place along entire southern and south 


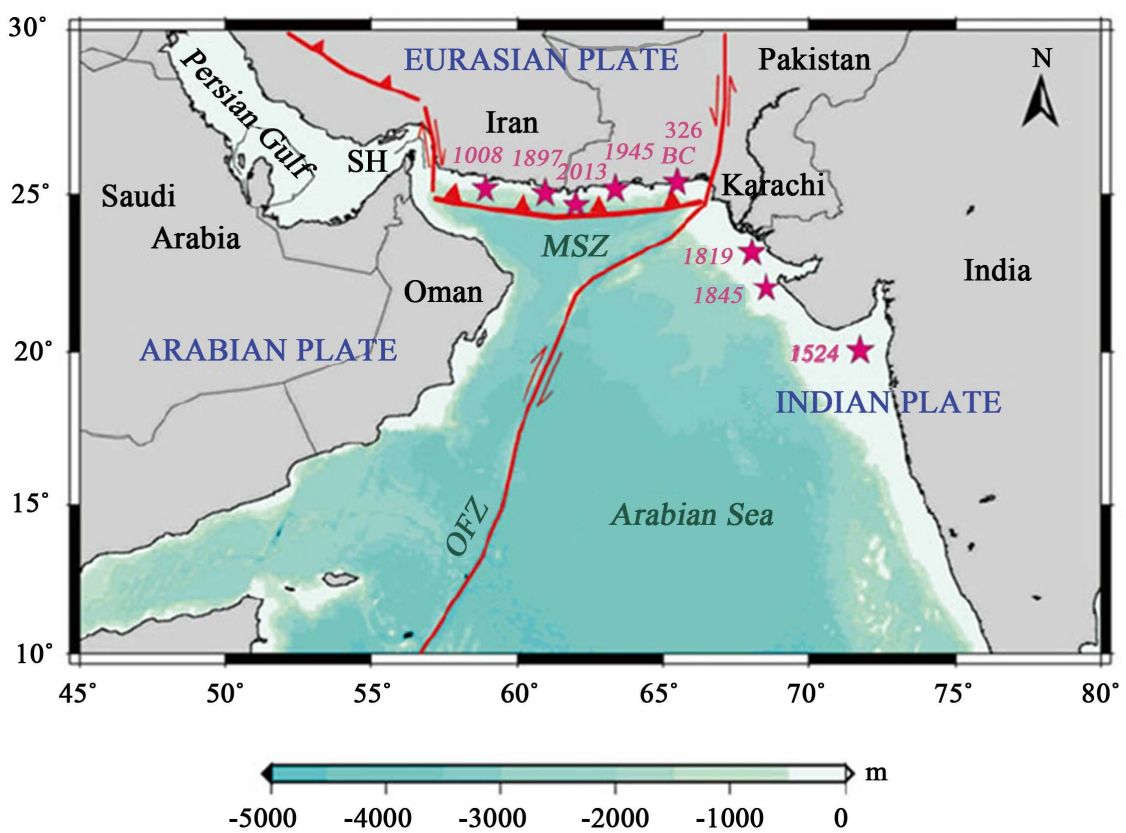

Figure 2. Tectonic map of the Arabian, Indian and Eurasian plates showing the location of the Makran accretionary prism of southeastern Iran and southern Pakistan (Star symbols = History of Tsunamis).

eastern boundary of Eurasian Plate as it collided with Indian plate and other micro plates. The northward movement and subduction of Oman oceanic lithosphere beneath Iranian micro-plate at a very shallow angle and at high rate is responsible for active orogenesis and uplift [19] [20]. A belt of highly folded and densely faulted coastal mountain ridges along the coastal region of Makran in Balochistan of Iran and Sindh coasts of Pakistan (Figure 3).

The Makran Accretionary Wedge (MAW) is a consequence of the subduction of the oceanic part of the Arabian plate beneath Eurasia (Lut and Afghan blocks). The MAW extends about $1000 \mathrm{~km}$ from southern Iran to the Baluchistan of Pakistan. It is separated from the Zagros Mountain Belt, to the west, by the dextral Minab-Zendan Transform Fault and to the east it is restricted by the sinistral Chaman Transform Fault System (Figure 4).

Seismic profiles document large normal fault systems near the coast (Figure 5), which are also found onland in the Coastal plain only [8]. The fact that normal faulting occurs along the coast only suggests a trench-parallel structural discontinuity, which is not well understood. This also raises the question as to whether the offshore and onshore fold and-thrust belts belong to the same active wedge and whether inland Makran is currently deforming. We will answer this question with evidence for active deformation.

The Makran Accretionary Wedge exposed in Iran was a progressively filled turbidite basin between the Middle Eocene and Middle Miocene times [10]. Four main thrust 8 sheets are separated by major thrusts. From North to south they are: North, Inner, Outer and coastal Makran (Figure 6). The general south-vergence suggests that folds and major thrusts form an imbricate structure due to bulk N-S 


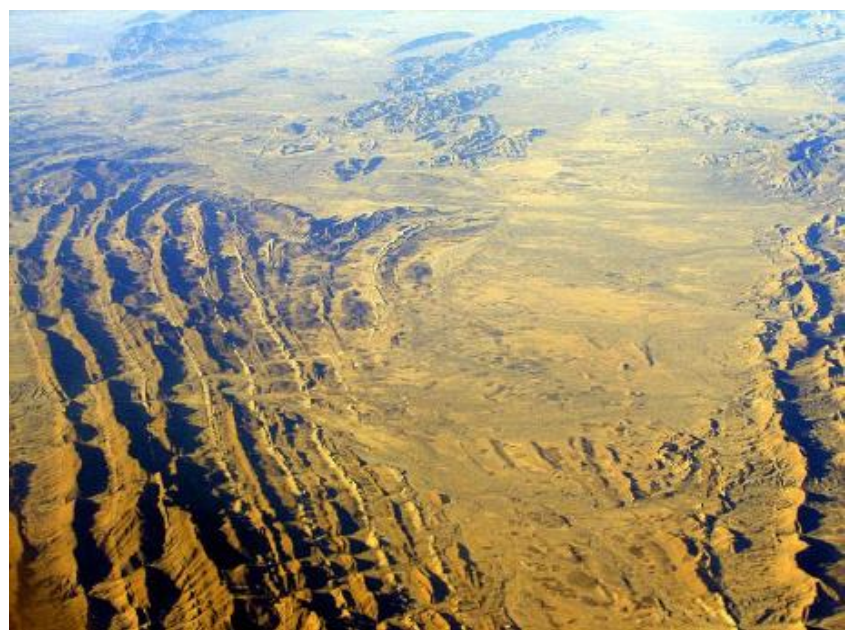

Figure 3. Aerial photograph of the study area.

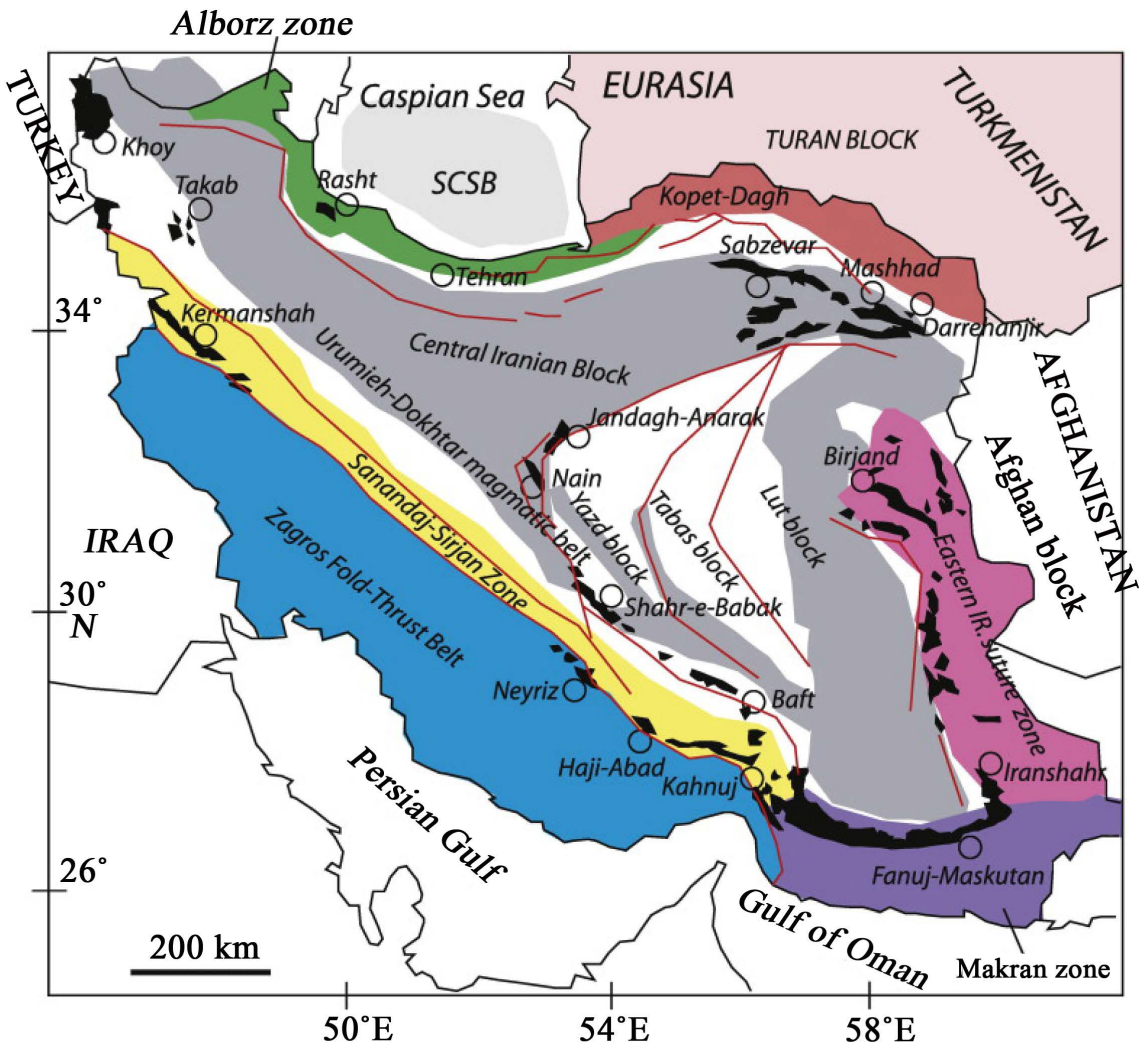




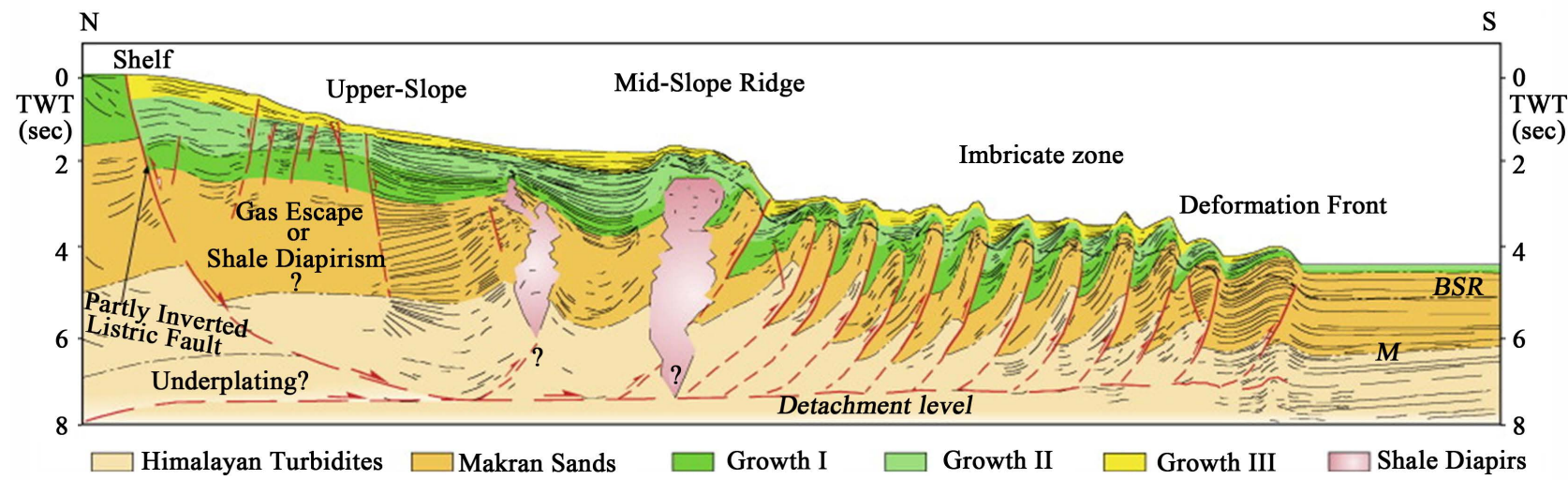

Figure 5. Regional N-S seismic profile across the western sector of the offshore Makran accretionary prism, west of Chabahar [21].

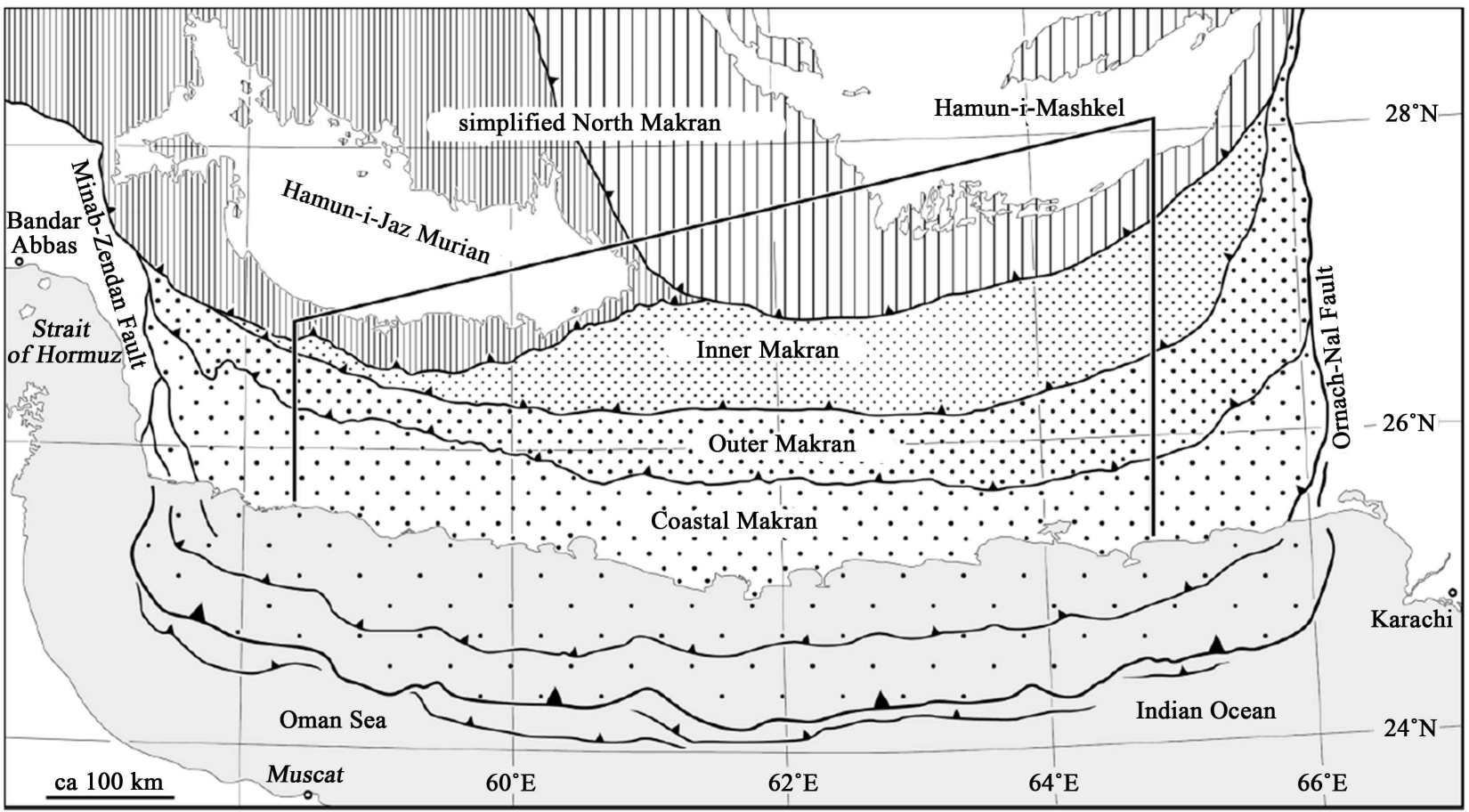

Figure 6. Simplified structural map of the onshore fold-and-thrust and offshore Makran accretionary wedge [21].

shortening. Deformation shifted the active, submarine wedge southward after emplacement of the olistrostrome, and coastal Makran evolved into a wedge-top basin with shallower water and continental sedimentation [20].

Systematic mapping and direct dating on these surfaces were needed and excellent exposure conditions detectable from satellite images were encouraging. Semi-arid climatic conditions with disseminated, poor vegetation and minimal soil cover make the inland Makran an excellent application where remotely sensed data may be used effectively to decipher rocks, structures and landforms (Figure 7).

Detailed image of a mud volcano, its channel and chamber which is full of shale. Note the presence of a thrust fault associated with the mud extrusion [21]. Field 


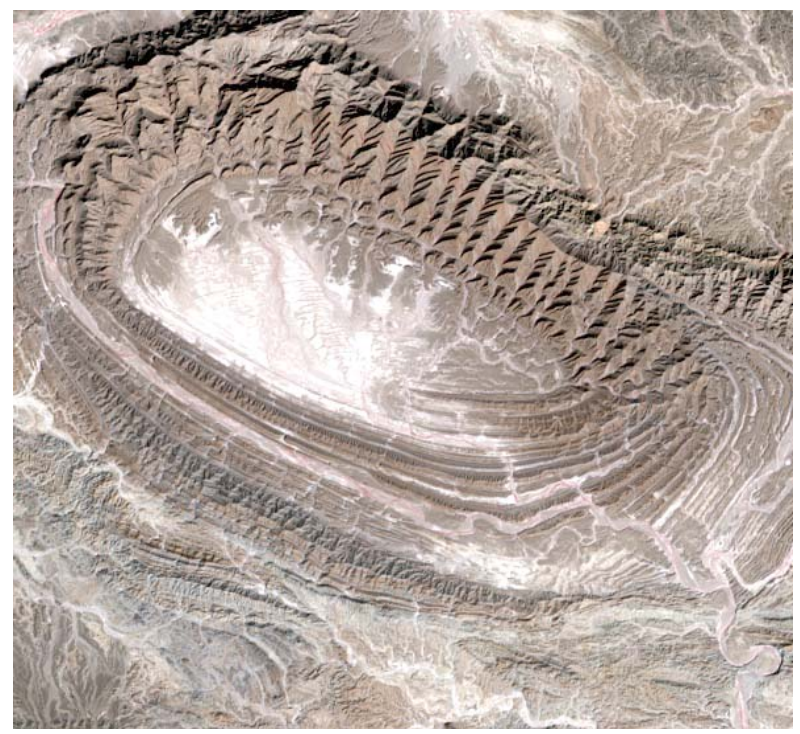

Figure 7. Satellite image of part of the studied area. The prominent synclines are upper Miocene (Tortonian-Messinian) sandstone-dominated sequences. Picture centered at $25^{\circ} 56^{\prime} 37.74 " \mathrm{E}, 59^{\circ} 58^{\prime} 58.34^{\prime \prime} \mathrm{N}$.

evidence such as Steep Mountains $1500 \mathrm{~m}$ (Height), uplifted terraces, mud-volcanoes and bare desert coastline the reason is active tectonic in Makran regions (Figure 8 and Figure 9).

Mud Volcanoes are well-known phenomena whereby fluid-rich, fine-grained sediments ascend within a lithologic succession because of their buoyancy. These processes have long been recognized as being related to the occurrence of petroleum, regional volcanic and earthquake activity, and orogenic belts. Most importantly, mud volcanoes occur along convergent plate margins where fluid-rich sediment is accumulated in deep-sea trenches at high rates. Such deposits then enter the subduction factory, where liquids and volatiles are released due to increasing compaction stress and temperature (Figure 9).

In summary, mud volcanism is most abundant in compressional and, to a lesser extent, in deltas of great rivers. As for the first, tectonic activity is an additional trigger to the buoyant driving mechanism. Fluid for mud volcanism is supplied from various sources, including meteoric and volcanic waters, pore water expulsion, hot springs, mineral dehydration reactions, and gas hydrate destabilization. In various areas the reasons for mud volcano formation are different. As a consequence, it is pointless to define a universal limited set of reasons. The expedient approach is to determine the key causative factors that can be used to forecast the areas of mud volcanic activity (Figure 10).

Excavated pit from the surface which was studied sediments. Paleotsunami deposits provide ability to extend the record of past tsunamis beyond recorded history and possibility of not only determining how often tsunamis occur in a given area, but also how large those tsunamis might have been. Tsunami sediments can be different from place to place, depends on the sediment source. Tsunami sediment forms a "blanket" of sand on land, often becoming thinner 

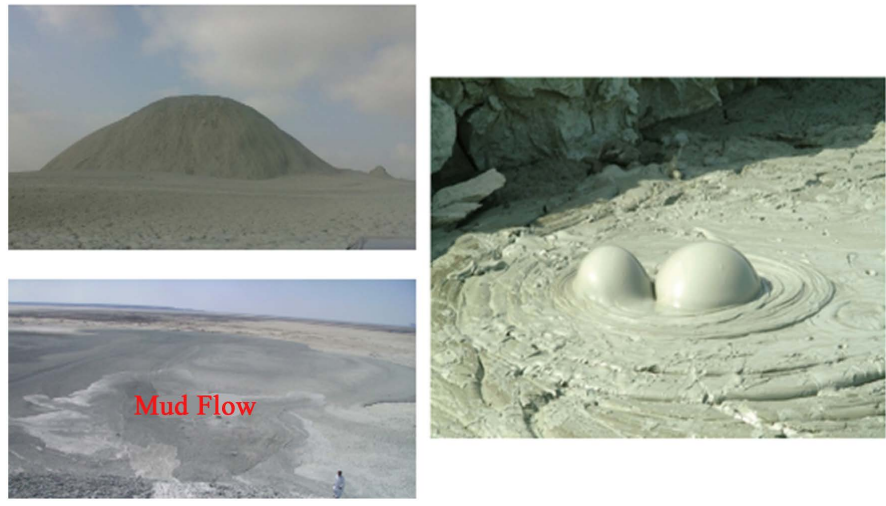

Figure 8. Mud volcano in makran zone.
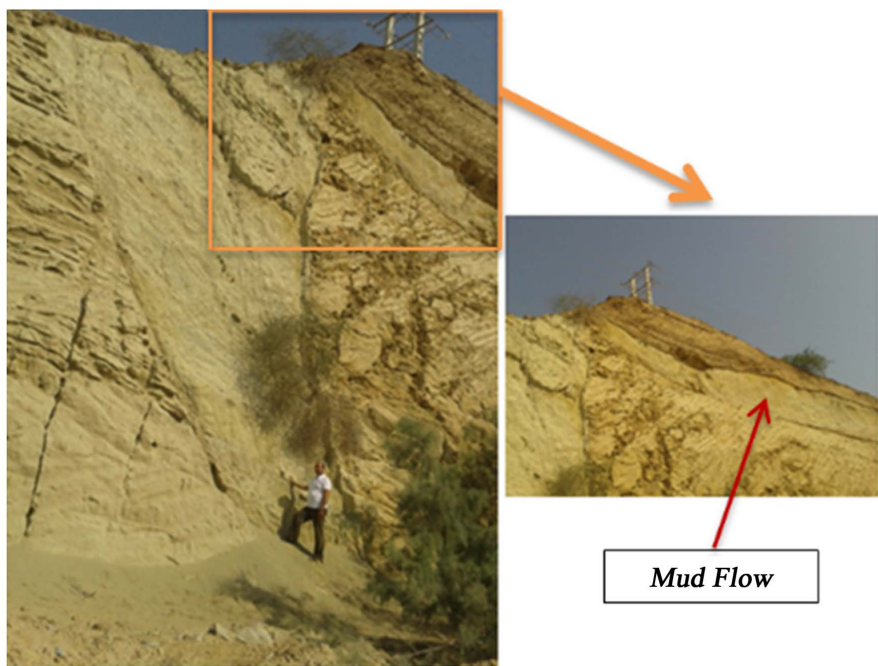

Figure 9. The cross section of an old mud volcano in Chabahar which disturbed the overlaying sedimentary rocks.

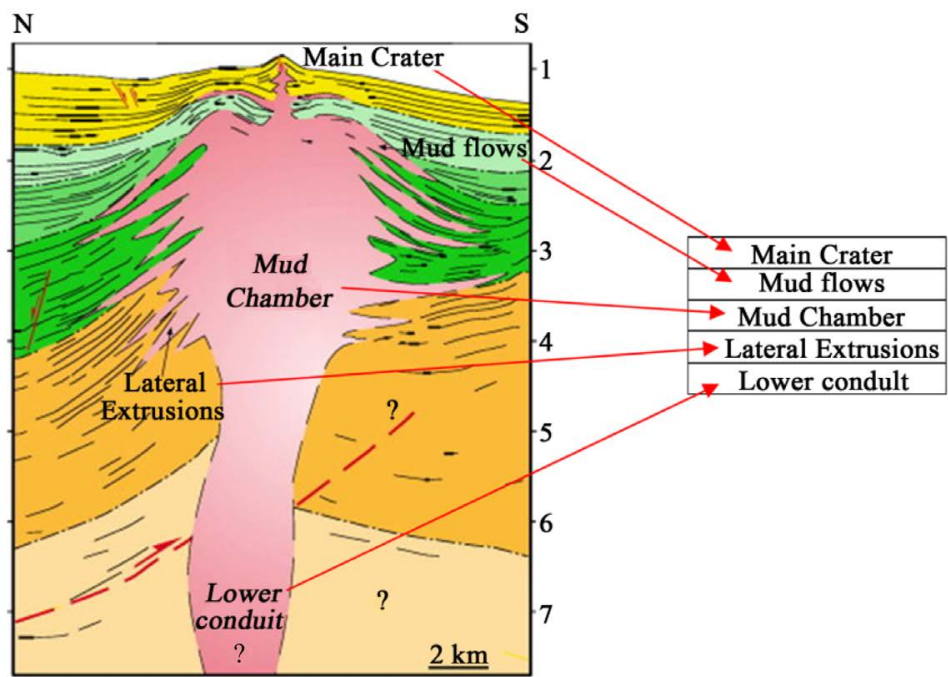

$\square$ Himalayan Turbidites $\square$ Makran Sands $\square$ Growth I $\square$ Growth II $\square$ Growth III $\square$ Mud voicano

Figure 10. Mud volcano formation in coasts of Makran (regional N-S seismic profile) [21]. 
landward, but more likely filling low spots and becoming thinner on high spots. Base of sediment shows erosion near the ocean but becomes purely depositional landward (Figure 11). Of course Often sedimentation from individual waves can be distinguished, with each pulse becoming finer landward and upward, although coarsening upward is common (especially in large tsunamis). Although fining appears to happen landward, it appears to occur as a kind of "shift" from one sediment population to another. This shift may be subtle, and probably is best explained as the landward shifting of available facies offshore.

In study area many broken shells of the throgh shell bivalvia were observed along the coastline of the Oman Sea tidal flats in 2007 (Gono storm). Hence, a number of infaunal organisms that were left exposed on the tidal flat surface are likely to be swept away by the tsunamis (Figure 12).

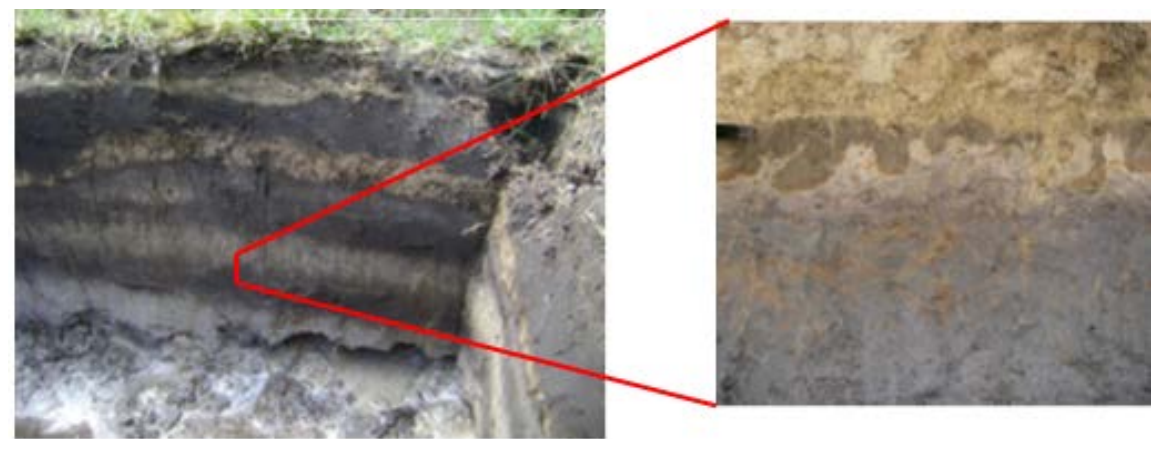

Figure 11. Excavated pit and close-up paleotsunami deposits.

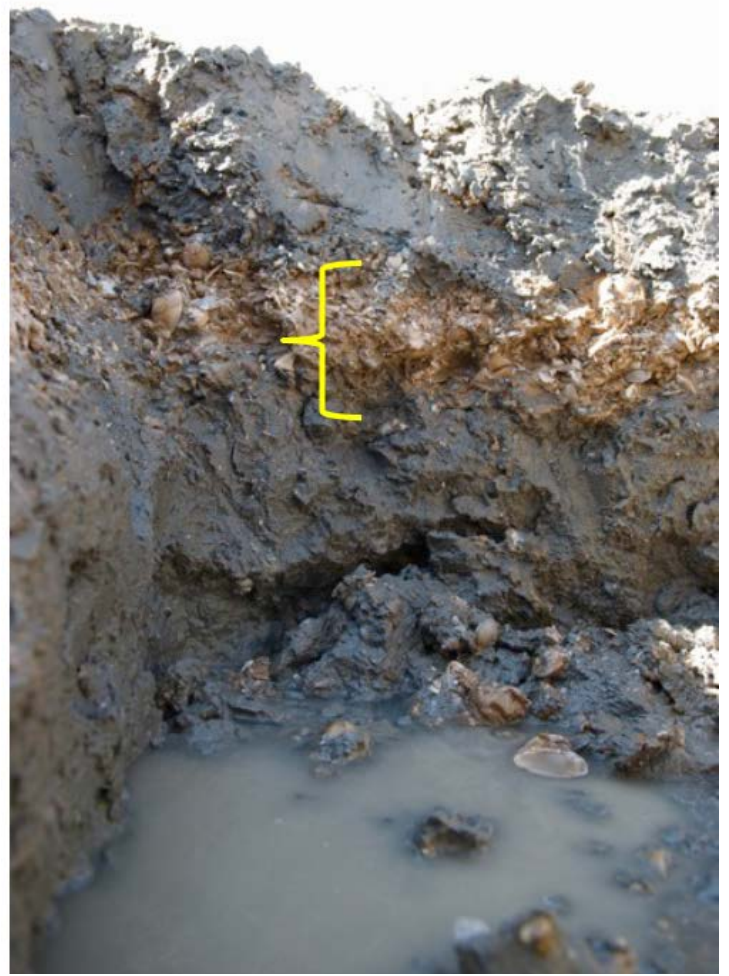

Figure 12. Shell to shell impacts as an index layer (paleotsunami deposits). 
In deposits shell of Bivalves fossils are impact chipping, stress fractures and angular fragments due to Shell to shell impacts and turbulent flow (Figure 13 and Figure 14).

The presence of any articulated offshore bivalve species out of life position indicates a rapid catastrophic event (tsunami) rather than a more prolonged storm, which would not cause transport of shells over several kilometers [22]. The shell bed is close to the modern lagoon surface, indicating recent deposition; the 1945 tsunami is the only significant event in recent past [23] [24] [25] [26]. This likely caused extensive scour of the sand platform in front of the lagoon, and the transport of in faunal bivalve species found in the shell unit. The scour offshore and within the lagoon ( $50 \mathrm{~cm}$ deep) eroded the offshore sand platform and the lagoon basin, depositing shells across the lagoons that were subsequently buried by post-tsunami sedimentation.

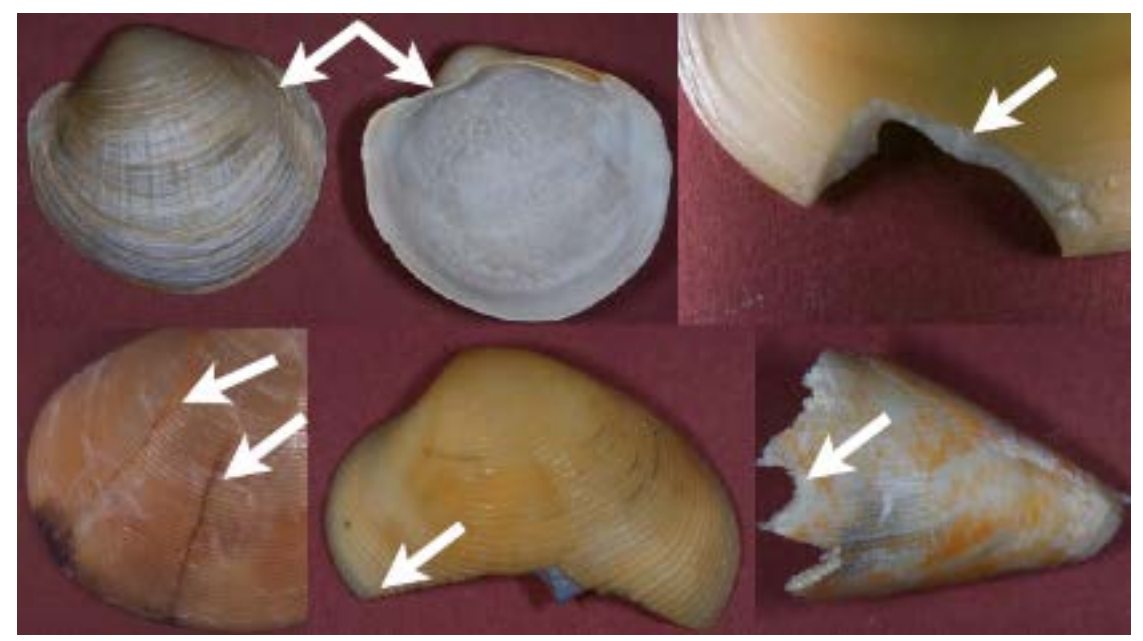

Figure 13. Damage shell to shell impacts (see white arrows in shells).

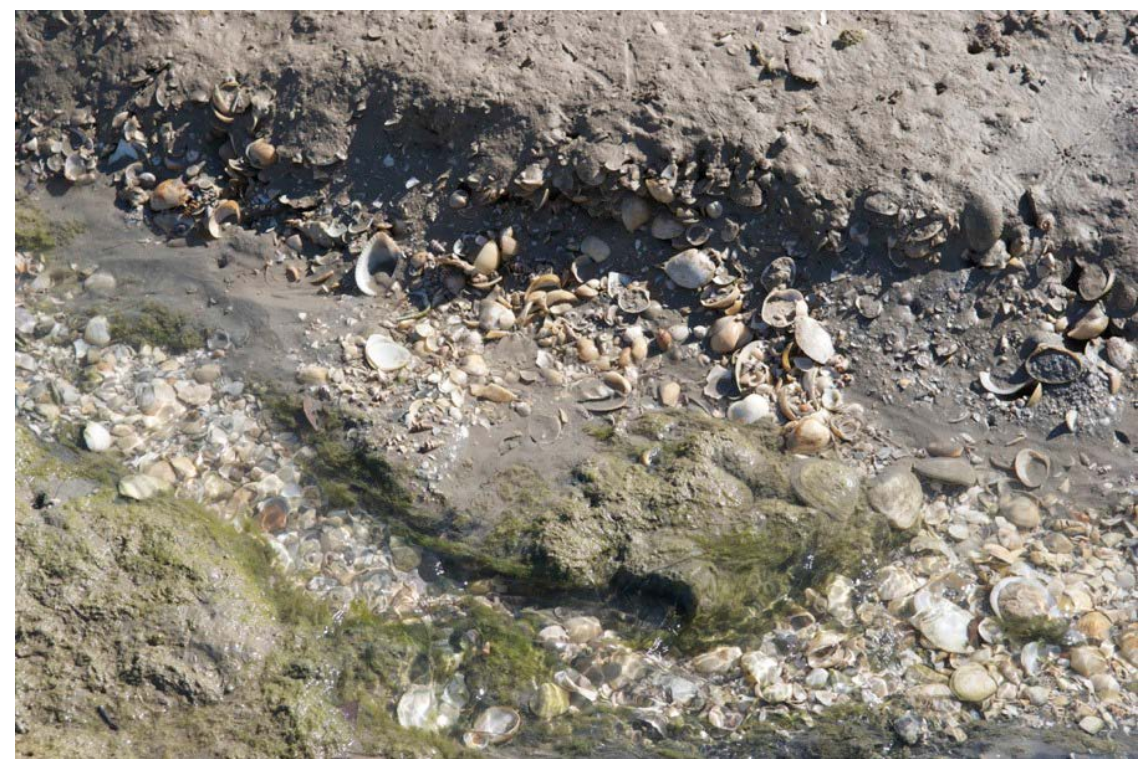

Figure 14. Index bed captain fossils due to shell to shell impacts and turbulent flow. 
Large storms have wide-ranging effects in a spectrum of environments from outer shelves to coastal plains. The most common deposits of storms in the rock record are sandstone beds deposited under powerful near-bottom water motions produced by waves and currents (Figure 15). Both tsunamis and large storms cause death and damage along low-lying coastal areas, and both occur with regularity, although tsunamis are much less frequent than coastal storms [27] [28] [29]. Because of their infrequency, tsunamis are poorly documented in historical records for many of the areas where they pose a threat. In these areas, interpreting the geologic record may be the only way to discover the history of past tsunamis and the likely hazard from future tsunamis. Both tsunamis and large storms, particularly hurricanes, are capable of inundating coastal areas and depositing sandy sediment over broad areas landward of the beach. Correctly identifying a sandy bed in the geologic record as either a tsunami or a storm deposit is critical for determining the frequency of each hazard. The origin and dynamics of the depositing flows were considered controversial and initial models relied on cross-shelf transport by turbidity currents. Actuality models of storm dynamics subsequently constructed by oceanographers and marine geologists largely focused on nearly shore-parallel geostrophic currents.

Tsunami deposits are generally less than $25 \mathrm{~cm}$ thick, extend hundreds of meters inland from the beach, and have an overall tendency to drape the preexisting landscape. They commonly consist of a single, homogeneous bed that grades from coarser grained at the bottom to finer grained at the top, or a bed with only a few thin layers. Mud clasts or thin layers of mud within the deposit are strong

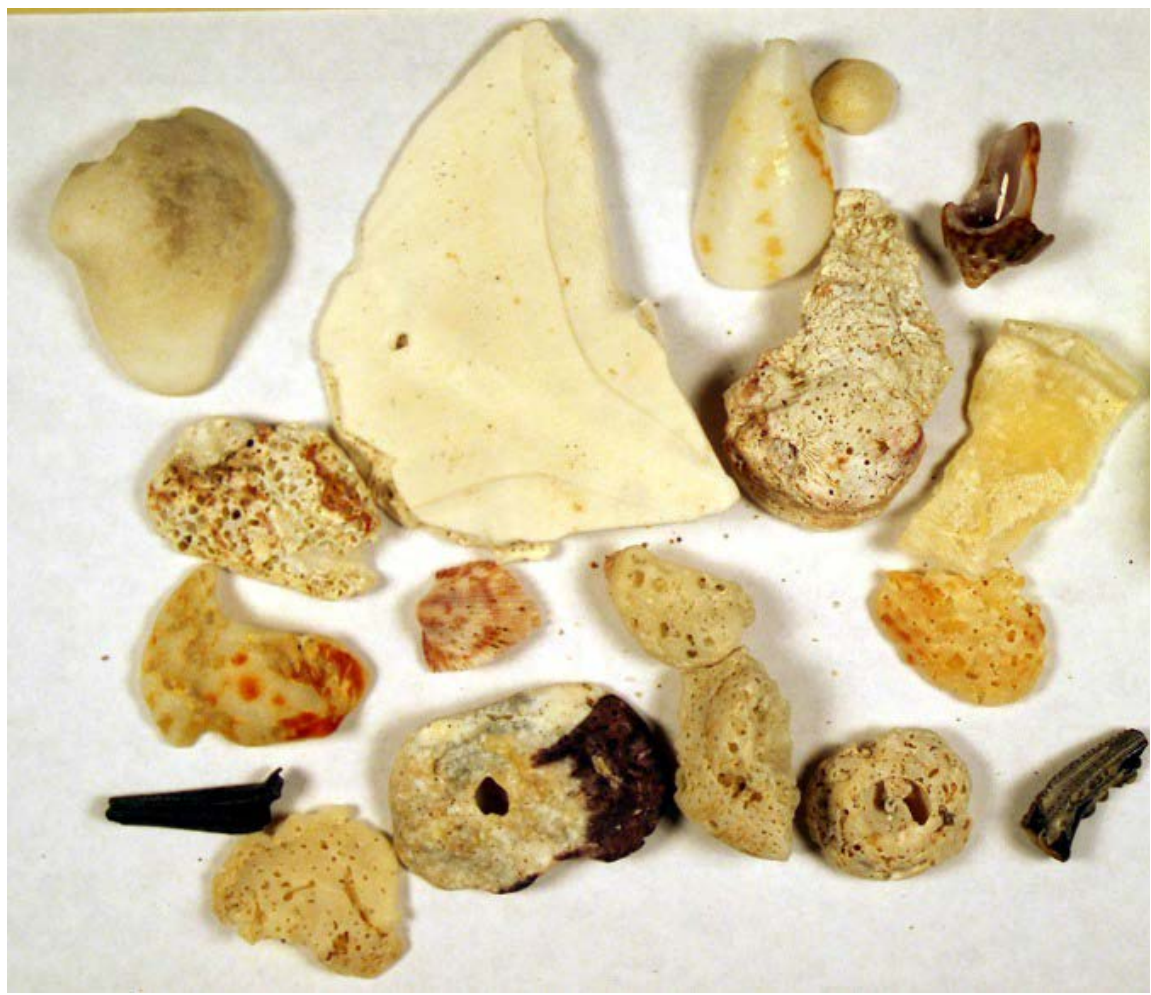

Figure 15. Storms deposits (Gono storm, 2007). 
evidence of tsunami origin. Twig orientation or other indicators of return (Seaward) flow during deposition of the sediment are also diagnostic of tsunami deposits. Tsunami deposits thicken and then thin landward, with a maximum deposit thickness typically more than $50 \mathrm{~m}$ inland from the beach because a zone of erosion commonly is present near the beach.

Storm deposits, in contrast, generally are more than $30 \mathrm{~cm}$ thick and will not advance beyond the low places they are able to fill in the preexisting topography. They typically consist of multiple lamina sets of extremely thin (less than $1 \mathrm{~cm}$ thick) layers called laminae. Features that favor storm deposits are the types of stratification associated with the transport of sediment by rolling and bouncing along the bottom (foresets, climbing ripples, backsets), and numerous thin (millimeters to a few centimeters) lamina-sets of alternating coarse and fine grain size indicative of high-frequency waves [30]. Abundant shell fragments organized in laminae also favor a storm origin. Storm deposits contain no internal mud layers and rarely contain pieces of mud. Maximum deposit thickness is near the shore, and landward thinning of the deposit is commonly abrupt. Storm deposits fill in topographic lows, and the upper surface is relatively uniform in elevation alongshore.

The Makran subduction zone extends cross-strike $400 \pm 600 \mathrm{~km}$ from the deformation front in the Oman Sea to the Baluchestan volcanic arc. Crustal phases are present on all lines, and are most pronounced on the southern stations. To the north a complex overburden increasingly attenuates the crustal phases. Field relations in the emergent part of the Makran accretionary prism show that a mid-Miocene to early Pliocene slope and shelf sedimentary sequence was deposited directly on abyssal-plain turbidites without any detectable stratigraphic or structural discordance. Sedimentological evidence for rapid shoaling, however, indicates that the underlying sediment column was tectonically thickened by a factor of between two and three during this period. This can be explained by large-scale under thrusting and under plating of sedimenta mode of accretion that is also favored by mass-balance considerations. The visible deformation in the coastal Makran occurred when the region was $70-100 \mathrm{~km}$ north of the contemporary prism front. The Makran Coastal Range is primarily made up of limestone and sandstone. It was formed when the northwestern Indian plate collided with the Asian plate (Figures 16-18).
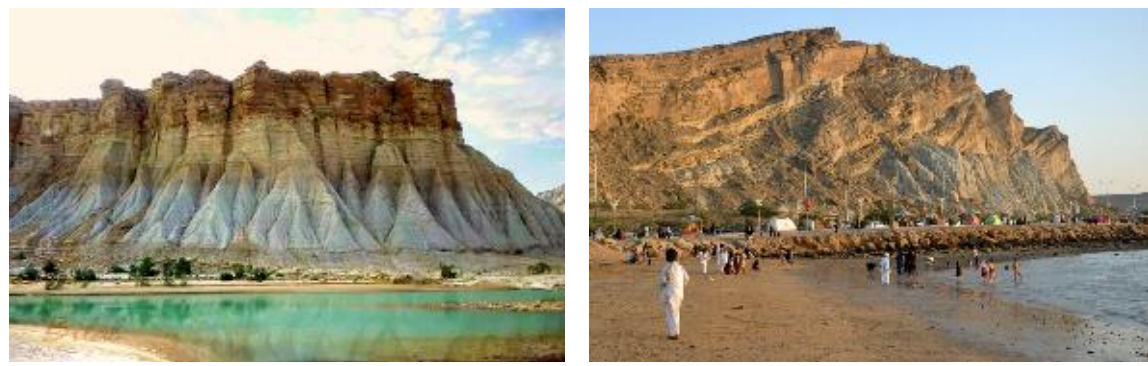

Figure 16. A wonderful aerial view of Makran coastal, the beach and the rock formations (Left: Horizontal cliff \& Ritgh: Uplifting bed). 


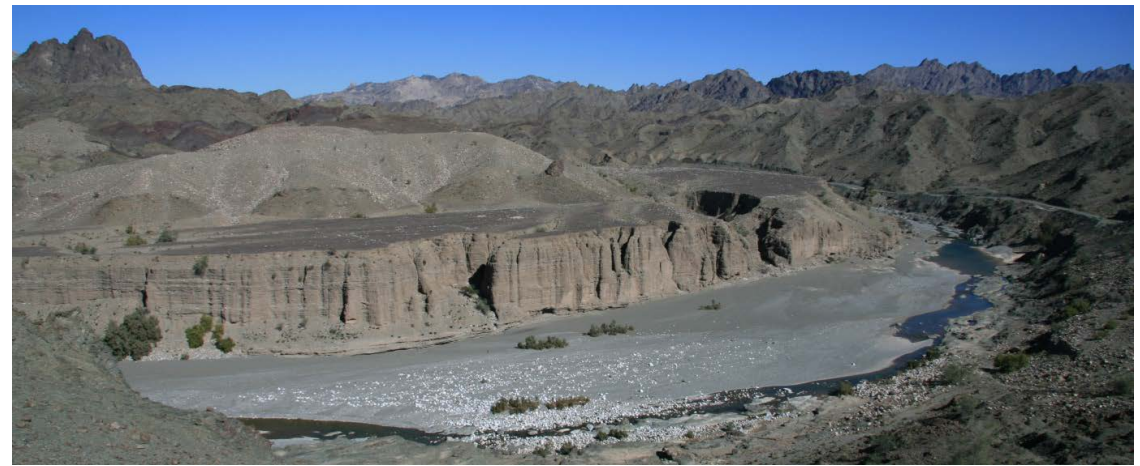

Figure 17. Fluvial landforms (terraces in meander partly covered by colluvion) and alluvial channel of the Fanuj River, seen from $26^{\circ} 28^{\prime} 08.2^{\prime \prime N}$; $059^{\circ} 38^{\prime} 19.7^{\prime \prime E}$. Rather regular spacing of stream channels in the background landscape reflects uniform erodibility of the underlying Eocene, shale-dominated turbidities.

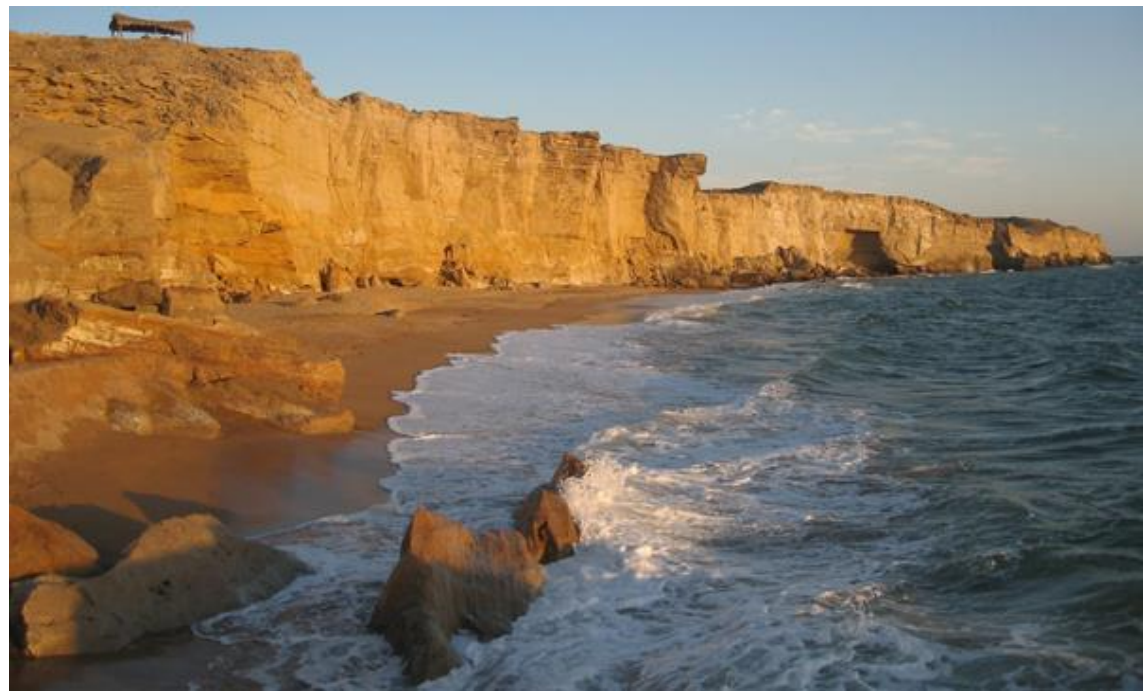

Figure 18. Photograph of marine terraces along the coast of Makran.

Detailed seismological and geological information in planning are extremely essential to avoid any disaster. It is to be remembered that seismicity does not remain fixed in an area but migrates slowly with time. Thus, the planners are expected to be more concerned with the building code and prevention strategies. It is also important to mention that the Coastal zones are always vulnerable to natural hazards and liquefaction.

\section{Conclusions}

This region which is located between the Zendan-Minab Fault System and Oranch-Nal Fault Zone shows relatively low seismicity in comparison with the surrounding region. The faults which are hidden or invisible may trigger anytime, hence are a warning to the authorities, planners, developers, and the corporate sector and cannot be overlooked.

The Makran subduction zone extends cross-strike $400 \pm 600 \mathrm{~km}$ from the deformation front in the Oman Sea to the Baluchestan volcanic arc. The Makran 
subduction zone can be the site of large earthquakes, as evidenced by the 1945 event. Recent developments in Plate Tectonics would suggest that there is no reason why the Makran would not feature events larger than the 1945 shock.

Semi-arid climatic conditions with disseminated, poor vegetation and minimal soil cover make the inland Makran an excellent application where remotely sensed data may be used effectively to decipher rocks, structures and landforms.

Excavated pit from the surface was studied sediments. Paleotsunami deposits provide ability to extend the record of past tsunamis beyond recorded history and possibility of not only determining how often tsunamis occur in a given area, but also how large those tsunamis might have been. Tsunami sediments can be different from place to place, depend on the sediment source. Tsunami sediment forms a "blanket" of sand on land, often becoming thinner landward, but more likely filling low spots and becoming thinner on high spots. Base of sediment shows erosion near the ocean but becomes purely depositional landward

Both tsunamis and large storms cause death and damage along low-lying coastal areas, and both occur with regularity, although tsunamis are much less frequent than coastal storms. Because of their infrequency, tsunamis are poorly documented in historical records for many of the areas where they pose a threat. In these areas, interpreting the geologic record may be the only way to discover the history of past tsunamis and the likely hazard from future tsunamis.

\section{References}

[1] Burg, J.-P., Dolati, A., Bernoulli, D. and Smit, J. (2012) Structural Style of the Makran Tertiary Accretionary Complex in SE-Iran. In: Al Hosani, K., Roure, F., Ellison, R. and Lokier, S., Eds., Lithosphere Dynamics and Sedimentary Basins: The Arabian Plate and Analogues, Springer Verlag, Heidelberg, 239-259.

[2] Kopp, C., Fruehn, E., Flueh, E., Reichert, C., Kukowski, N., Bialas, J. and Klaeschen, D. (2000) Structure of the Makran Subduction Zone from Wide-Angle and reflection Seismic Data. Tectonophysics, 329, 171-191. https://doi.org/10.1016/S0040-1951(00)00195-5

[3] DeMets, C., Gordon, R.G. and Argus, D.F. (2010) Geologically Current Plate Motions. Geophysical Journal International, 181, 1-80. https://doi.org/10.1111/j.1365-246X.2009.04491.x

[4] Regard, V., Hatzfeld, D., Molinaro, M., Aubourg, C., Bayer, R., Bellier, O., Yamini-Fard, F., Peyret, M. and Abbassi, M. (2010) The Transition between Makran Subduction and the Zagros Collision: Recent Advances in Its Structure and Active Deformation. Geological Society, London, Special Publications, 330, 43-64. https://doi.org/10.1144/SP330.4

[5] Aghanabati, S.A. (2010) Geology of Iran. Geological Survey of Iran, 578 p.

[6] Dominey-Howes, D., Humphreys, G. and Hesse, P. (2006) Tsunami and Palaeotsunami Depositional Signatures and Their Potential Value in Understanding the Late-Holocene Tsunami Record. The Holocene, 16, 1095-1107. https://doi.org/10.1177/0959683606069400

[7] Abdideh, M., Qorashi, M., Rangzan, K. and Arian, M. (2011) Assessment of Relative Active Tectonics Using Morphometric Analysis, Case Study of Dez River (Southwestern, Iran). Geosciences Scientific Quarterly Journal, 20, 33-46.

[8] Dolati, A. (2010) Stratigraphy, Structure Geology and Low-Temperature Thermochronology across the Makran Accretionary Wedge in Iran. PhD Thesis, ETH 
Zurich, Zurich, 309 p.

[9] McCall, G.J.H. (2002) A Summary of the Geology of the Iranian Makran. In: Clift, P.D., Kroon, F.D., Gaedecke, C. and Craig, J., Eds., The Tectonic and Climatic Evolution of the Arabian Sea Region, Special Publication 195, Geological Society, London, 147-204. https://doi.org/10.1144/GSL.SP.2002.195.01.10

[10] Burbank, D.W. and Anderson, R.S. (2001) Tectonic Geomorphology. Blackwell Science, Malden, $273 \mathrm{p}$.

[11] Kirby, E., Whipple, K.X., Tang, W. and Chen, Z. (2003) Distribution of Active Rock Uplift along the Eastern Margin of the Tibetan Plateau: Inferences from Bedrock Channel Longitudinal Profiles. Journal of Geophysical Research, 108, 2217 p.

[12] Kirby, E. and Whipple, K.X. (2012) Expression of Active Tectonics in Erosional Landscapes. Journal of Structural Geology, 44, 54-75.

[13] Bull, W.B. (2007) Tectonic Geomorphology of Mountains. A New Approach to Paleoseismology. Blackwell Publishing Ltd., Oxford, 316 p. https://doi.org/10.1002/9780470692318

[14] Bull, W.B. (2009) Tectonically Active Landscapes. Wiley-Blackwell, Chichester, 326 p. https://doi.org/10.1002/9781444312003

[15] Anderson, R.S. and Anderson, S.P. (2010) Geomorphology: The Mechanics and Chemistry of Landscapes. Cambridge University Press, Cambridge, 637 p. https://doi.org/10.1017/CBO9780511794827

[16] Hammer, O. and Harper, D.A.T. (2006) Paleontological Data Analysis. Blackwell Publishing, Malden, $351 \mathrm{p}$.

[17] Bagha, N., Arian, M., Ghorashi, M., Pourkermani, M., El Hamdouni, R. and Solgi, A. (2014) Evaluation of Relative Tectonic Activity in the Tehran Basin, Central Alborz, Northern Iran. Geomorphology, 213, 66-87.

[18] Moghimi, H., Arian, M. and Sorbi, A. (2015) Fault Movement Potential of Marzanabad Area, North Alborz, Iran. Open Journal of Geology, 5, 126-135. https://doi.org/10.4236/ojg.2015.53012

[19] Regard, V., Bellier, O., Thomas, J.C., Abassi, M.R., Mercier, J., Shabanian, E., Fefhhi, K. and Soleymani, S. (2004) Accommodation of Arabia-Eurasia Convergence in the Zagros-Makran Transfer Zone, SE Iran: A Transition between Collision and Subduction through a Young Deforming System. Tectonics, 23, TC4007. https://doi.org/10.1029/2003TC001599

[20] Quittmeyer, R.C. and Jacob, K.H. (1979) Historical and Modern Seismicity of Pakistan, Afghanistan, Northwestern India and Southeastern Iran. Bulletin of the Seismological Society of America, 69, 773-823.

[21] Grando, G. and McClay, K. (2007) Morphotectonics Domains and Structural Styles in the Makran Accretionary Prism, Offshore Iran. Sedimentary Geology, 196, 157-179.

[22] Kortekaas, S. and Dawson, A.G. (2007) Distinguishing Tsunami and Storm Deposits: An Example from Martinhal, SW Portugal. Sedimentary Geology, 200, 208-221.

[23] Szuman1, M., Berndt, C., Jacobs, C. and Best, A. (2006) Seabed Characterization through a Range of High-Resolution Acoustic Systems-A Case Study Offshore Oman. Marine Geophysical Researches, 27, 167-180.

[24] Poroohan, N., Pourkermani, M. and Arian, M. (2013) An Assessment of Relationship in F-Parameter and Paleostress Fields in Heterogeneous Lithologies: Roudbar Area (Northwest of Iran). Australian Journal of Basic and Applied Sciences, 7, 
933-942.

[25] Arian, M. and Aram, Z. (2014) Relative Tectonic Activity Classification in the Kermanshah Area, Western Iran. Solid Earth, 5, 1277-1291. https://doi.org/10.5194/se-5-1277-2014

[26] Arian, M. (2013) Physiographic-Tectonic Zoning of Iran's Sedimentary Basins. Open Journal of Geology, 3, 169-177. https://doi.org/10.4236/ojg.2013.33020

[27] Arian, M. and Noroozpour, H. (2015) The Biggest Salt-Tongue Canopy of Central Iran. Open Journal of Geology, 5, 55-60. https://doi.org/10.4236/ojg.2015.52005

[28] Arian, M. and Noroozpour, H. (2015) Tectonic Geomorphology of Iran's Salt Structures. Open Journal of Geology, 5, 61-72. https://doi.org/10.4236/ojg.2015.52006

[29] Rahimi, N. and Arian, M. (2014) Tectonic Geomorphplogy of Hamedan-Sosangerd Region, West Iran. Advances in Environmental Biology, 8, 119-124.

[30] Vernant, P., Nilforoushan, F., Hatzfeld, D., Abbassi, M.R., Vigny, C., Masson, F., Nankali, H., Martinod, J., Ashtiani, A., Bayer, R., Tavakoli, F. and Chéry, J. (2004) Present-Day Crustal Deformation and Plate Kinematics in the Middle East Constrained by GPS Measurements in Iran and Northern Oman. Geophysical Journal International, 157, 381-398. https://doi.org/10.1111/j.1365-246X.2004.02222.x

\section{Submit or recommend next manuscript to SCIRP and we will provide best} service for you:

Accepting pre-submission inquiries through Email, Facebook, LinkedIn, Twitter, etc. A wide selection of journals (inclusive of 9 subjects, more than 200 journals)

Providing 24-hour high-quality service

User-friendly online submission system

Fair and swift peer-review system

Efficient typesetting and proofreading procedure

Display of the result of downloads and visits, as well as the number of cited articles

Maximum dissemination of your research work

Submit your manuscript at: http://papersubmission.scirp.org/

Or contactojg@scirp.org 